\title{
Bodies on the Line: Contact Improvisation and Techniques of Nonviolent Protest
}

\author{
Danielle Goldman
}

0 $\mathrm{n}$ the morning of May 4, r96r, a brave and motley group of travelers-seven black males, three white males, and three white females, varying in age and professional standing but all trained in nonviolence-embarked on what they called the "Freedom Ride." Designed by the Congress of Racial Equality (CORE), the bus ride was meant to commemorate and further the organization's I 947 Journey of Reconciliation, a nonviolent test of desegregation on interstate buses that quickly disintegrated in the face of staunch resistance. This time, riders would test the I 960 Supreme Court decision Boynton v. Virginia, which prohibited segregation in the waiting rooms and restaurants of bus terminals (Branch I 989, 390). Departing from Washington, D.C., the Freedom Ride aimed to arrive in New Orleans on May 17 , the seventh anniversary of Brown $v$. Board of Education. Explaining that they were merely exercising rights granted by the Supreme Court but that they knew the dangers, CORE director James Farmer said, "We were prepared for the possibility of death" (Cozzens 1997). Riding the momentum of the student sit-ins, the civil rights movement had become for many a matter of "putting your body on the line" (Branch r 989, 392).

Before departing the thirteen freedom riders divided themselves onto two buses. The first week passed without incident. But early on May i I the riders had their first violent encounter. Having pulled into the Greyhound terminal in Rock Hill, South Carolina, John Lewis, a member of the Student Nonviolent Coordinating Committee (SNCC) and the youngest freedom rider, positioned himself as "first tester," making his way toward the whites' waiting room. The atmosphere was predictably tense. Two white youths quickly blocked the entrance, backed by roughly twenty others. Directed toward the colored entrance to the station, Lewis calmly delivered his standard speech, "I have a right to go in here on grounds of the Supreme Court decision in the Boynton case" (Branch I 98 ,

Danielle Goldman earned her PhD from the Department of Performance Studies at New York University. She received the 2005 Gertrude Lippincott Award and the 2006 Deena Burton Memorial Award for Outstanding Dissertation Research. She is currently writing a book on improvisation while teaching in the Department of Dance at Barnard College. In fall 2007 she will start as an assistant professor of dance at The New School. Having performed for six years with Troika Ranch, she recently completed projects with Anna Sperber and D. D. Dorvillier. 
4I 5). "Shit on that," was the white youth's reply, as he punched Lewis in the stomach. Hit hard, Lewis fell to the ground, and Albert Bigelow, a fellow freedom rider trained in the tactics of nonviolent protest, quickly positioned himself between Lewis and his surging attackers (4I5).

Although Bigelow responded spontaneously, it is important to recognize that his reaction resulted from mental, spiritual, and physical training. Both Bigelow and Lewis had attended workshops in nonviolent direct action, where they prepared themselves for situations of duress. CORE had conducted workshops in nonviolence since the r 94os. In these workshops participants engaged in spiritual and philosophical discussions, realizing that "Christianity needed to be modified for politics, and Gandhism modified for American culture" (259). James Lawson, who spent several years in India studying Gandhi's use of nonviolence, conducted workshops in Nashville during the late I 950 , where he prepared students for a range of demonstrations, including marches, picket lines, and sit-ins. According to Branch, "Lawson and the other new American Gandhians approached their projects with the care of a chemist. Each step was meticulously planned, executed, and evaluated, with an eye toward isolating behavior and control in response" (260). Their preparations for protest constituted a vital type of research.

In this article I will discuss intersections between the physical techniques that freedom riders drew upon and early innovations in contact improvisation, a partnered form of improvised dance spearheaded by Steve Paxton in the mid-I 970s. Previously a dancer in the Merce Cunningham Dance Company and an active participant in the Judson Dance Theater, Paxton explored how bodies move when still or when falling and sought ways to improvise within unfamiliar situations. What emerged was an improvisational mode of dance making where partners move in and out of contact with each other. Although postmodern dance and techniques of nonviolent protest emerged out of distinct histories, traditions, and social demands, by highlighting subtle ways in which their movement explorations coincide, I hope to re-examine the politics of contact improvisation in the early years of its development.

Other scholars have garnered revealing insights by analyzing nonviolent direct action from the perspective of dance studies. In 2003 Susan Foster wrote an article in Theatre Journal entitled "Choreographies of Protest." Discussing the lunch-counter sit-ins of 1960 , the ACT-UP die-ins that occurred two decades later, and the World Trade Organization (WTO) protests in Seattle in 1999, Foster explains that she does not view these events as dances, "for that would radically decontextualize their motivation and intent" (2). However, she does view these events as a dance scholar, interested in choreography, spectatorship, and signification. She describes the three protests, noting the training that activists underwent and the conscious positioning of their bodies in relation to changing structures of power. Intent on contesting "'the volcanic view' of protest as purely spontaneous and lacking in form or technique," Foster asks an important question: "How have these bodies been trained, and how has that training mastered, cultivated, or facilitated their impulses?" (2).

Barbara Browning also is interested in the choreography of political struggle. In "Choreographing Postcoloniality: Reflections on the Passing of Edward Said," Brown- 
ing highlights the dangers of referring to figures such as C. L. R. James, Frantz Fanon, and Mahatma Gandhi as choreographers. But she nevertheless proceeds, claiming that "righteous political struggle has had and will continue to have choreographic elements, and politicized dance performance will continue to remind us of the legacy of anticolonial struggle"(Browning 2004, I68). After admitting, somewhat hesitantly, to urging students to consider the "choreographic force" of Gandhi's march on the Dharasana Salt Works, she notes:

Nonviolent noncooperation requires a technique of the body which in many ways resembles what contemporary choreographers refer to as "release technique"but in the charged context of civil disobedience, the movement technique has intense political as well as spiritual ramifications. In 1930 the extraordinary bodily control of thousands of anticolonial protesters who resisted violence embodied a technique that would come to be understood as aesthetically "postmodern" but should be read, even today, as postcolonial in its implications and resonances.

( 169 )

In recognizing that techniques of nonviolent protest resemble instances of postmodern "release technique," Browning paves the way for my discussion of contact improvisation. Without question contact improvisation was a predominantly white venture, conducted in the safety of gymnasiums, lofts, and dance studios. Moreover, as Browning argues, movement technique in the charged context of civil disobedience has intense political as well as spiritual ramifications not found in the dance studio. Nevertheless, early contact improvisers investigated small units of movement, at times imperceptible to an outside observer, seeking choices and opportunities for agency-ways to improvise-within extreme situations, most notably while in the act of falling. Although much has been written about contact improvisation's democratic ideals, I am interested in the quest for improvisational possibility during the early years of the form's development, when falling seemed dangerous and the idea of "sharing a dance" was not something to be taken for granted.' At its core, contact improvisation is a practice of making oneself ready for a range of shifting constraints. When one looks to historical situations such as the freedom rides, in which people have "put their bodies on the line," one begins to see the power of a bodily training such as contact improvisation that seeks calm, confident choices even in situations of duress.

\section{Acquiring Technique}

As evidenced by the Freedom Rides, activists in organizations such as CORE engaged in philosophical and spiritual discussions about nonviolence as part of their training. They also carefully considered how they moved. Of particular relevance for the field of dance studies, many civil rights protesters explored the strategic value of falling, slack musculature, and stillness. They also recognized the need for improvisation. This becomes particularly clear in A Manual for Direct Action, written in 1964 by civil rights activists Martin Oppenheimer and George Lakey, with a forward by Bayard Rustin, who organized 
the 1947 Journey of Reconciliation and the 1963 March on Washington. Having written a guide for people interested in social change, the authors realized that preparation and training are essential for nonviolent direct action. But they also realized that one cannot provide a set of instructions that would "solve all problems for all time" (vii). It is hard to generalize because one can never know in advance what will happen in moments of confrontation. Therefore, out of necessity civil rights activists trained themselves to become creative improvisers. As one freedom rider described an attempt at a Mississippi jail-in to support the Freedom Rides, "It was a heroic effort at organization improvised under the most difficult conditions" (Meier and Rudwick 1973, 140).

As a dance scholar I am particularly interested in A Manual for Direct Action because it contains a great deal of physical description. For example, the authors explain that there are two basic options for responding to a physical attack: stand up and try to make eye contact with the attackers, or fall down. They argue that showing one's face and asking calm questions like "Do you know me? What have I done?" often diffuses violent confrontations. But falling was a widely used method of protecting oneself, as well as others under attack. They explain,

It [falling] is intended to protect the most vital parts of the body, through adopting a crouching position with hands over the head and ears, while lying on the ground. If a buddy is undergoing severe attack, and is on the ground, it is often wise to lace yourself between the attackers and the victim by means of falling over the victim, face down, approximating the position of a person doing a "pushup" on the "up" part, but keeping your face down and tucked into your chest. (93)

Activists also explored the strategic use of slack musculature and stillness. According to Oppenheimer and Lakey, protestors have the right to demand certain kinds of information from their leaders, including a clear sense of the demonstration's purpose, a plan for concluding the action, and whether or not arrest will be likely. Interestingly, the authors also note that protesters have the right to know "the pros and cons of going limp" ( 107 ). In a footnote the authors explain: "Going limp' is just what the phrase implies. It is a relaxation of all of the body in a kind of physical non-cooperation with the situation, so that the non-cooperator has to be dragged or carried to wherever authorities want him moved" (107). A few pages later, when discussing possibilities for agitation within a jail, the writers explain that one method is to sit down when outside of a cell or while being moved from one place to another. They state, "An important precaution here is that you should relax your body as much as possible, for tissue can be damaged and torn when you are lifted or dragged if your muscles are tensed" ( I I 2 ).

Although both falling and "going limp" had clear benefits, enabling resistance and diminishing injury, these physical states had social implications that protesters continuously negotiated. For example, demonstrators frequently asked, "Shall we sacrifice our dignified appearance (which has public relations value and maintains a certain personal worth) in order to refuse cooperation with an unjust situation?" (ro7). Similar questions emerged with the deployment of stillness, also linked with stereotypical images of passivity or compliance that had much to do with gender and race. Susan Foster notes this 
in her discussion of the student sit-ins, where protestors remained "utterly motionless" when requesting to be served at segregated lunch counters. According to Foster, "The stillness of the protestors'bodies seemed to some to reinforce the stereotype of the passive Negro waiting expectantly for consideration, and this prompted some to defy the pact of nonviolence by taking up a more aggressive and retaliatory plan of action. Yet stillness also gave them a powerful position from which to exert a sense of agency" $(2003,8)$.

\section{"Here Are the Facts"}

Although few people would consider Ralph Ellison a dance scholar, his novel Invisible Man illuminates relations between postmodern bodily practices and techniques of nonviolent protest, illustrating some of the powerful narratives at play as protestors assessed the pros and cons of their movement. One of the most striking scenes in Ellison's novel about race in America-first published in 1947, the same year as CORE's Journey of Reconciliation-involves a degrading display of dancing Sambo marionettes. Through troubling instances in which spectators are entertained by objects that leap or collapse upon command, the scene encapsulates the most pressing struggles of Invisible Man, a novel rife with falling bodies.

"Here are the facts. He was standing and he fell. He fell and he kneeled. He kneeled and he bled. He bled and he died" (Ellison I 947, 456). So Invisible Man's narrator eulogizes the death of Tod Clifton, a dynamic youth leader in Harlem who abandons his activist work late in the novel only to be killed on the street soon afterward by a white police officer for selling paper Sambo dolls without a permit. When the narrator first encounters Clifton hawking the dolls, he is appalled at the racist kitsch. But his reaction becomes more complex after Clifton's death, when he realizes that the grinning dolls were in fact horrifying marionettes manipulated by Clifton. Viewing the dolls as "an obscene flouncing of everything human," the narrator examines a paper marionette and exclaims, "The political equivalent of such entertainment is death" (386).

Perhaps the most salient thing to emerge from Ellison's fictional account of marionettes is the desire for autonomous action. Upon discovering fine black thread attached to the paper dolls, the narrator repeatedly asks, "What had made it seem to dance?"Before his death Clifton had used this same question of causality to taunt and entertain the crowd gathered around him, which was enthralled by the dancing dolls: "What makes him happy, What makes him dance, This Sambo, this jambo, this high-stepping joy boy?" (432). While these questions apply most obviously to the dolls, they also apply to Clifton. The narrator describes Clifton as young, charismatic, and full of potential-a fellow activist in the communist "brotherhood"-and he cannot fathom why or how Clifton could have "plunged" into a situation where he performed such degrading acts in public. According to the narrator, something must have made Clifton fall. With great agony, the narrator repeatedly asks who or what could have been responsible. The persistence with which this question appears emphasizes its terrible complexity, bound with a fraught history of racism and the desire for willful mobility as opposed to passivity.

In "Which Way Is Down? Improvisations on Black Mobility," Jason King explains 
that, historically, black communities in the United States have linked verticality with activism and horizontality with apathy. According to King, these associations are grounded in narratives of racial uplift and the metaphorical "ladder," symbolizing the social mobility in American life made possible by personal will $(2004,432)$. King traces the rhetoric of uplift, from its initial popularization by Booker $T$. Washington in the late nineteenth century through the black pride movement. According to this view, "Racial progress demands ... secure footing [and] resistance against the pull of gravity" (3I ). King shows the prominence of uplift philosophy's metaphors, citing their appearance in a range of figures, from Malcolm X to Bob Marley, all of whom urge their listeners to "stand up."

Interestingly, the end of King's essay complicates matters, as he notes the exhaustion that frequently accompanies the demands of uplift. According to King, "Uplift requires labor, but in time, exhaustion sets in. Following the display of too much pride, one supposedly falls. But must the fall, downward mobility, result in shame?" (35). Answering this question, King notes Hip Hop, black punk, and the "down low phenomenon" of the late r 990 , a term from Hip Hop identifying men who have secret gay sex rather than adhering to the basic tenets of the pride movement, prizing visibility. The bus protests symbolized by Rosa Parks, along with the sit-ins of the I96os and the workshops that informed actions like the freedom rides, were part of this experimentation. All of these instances recuperate "falling" as having value in political struggle. King explains, "No deadend is really an end. One can find pride crouching low to the ground, moving under the radar, not just up high, in the air" (40). A few pages later King proclaims, "Black performance moves toward the co-presence of mobility and immobility, control and freedom. ... Blackness is ambivalent direction, finding the fall in the ascent, and the ascent in the fall. This is survival" $(42)$.

Both Ellison and King illustrate a sliver of the history, material conditions, and powerful narratives that warn against aestheticizing passivity, often accomplished via limp images of falling or still bodies. As noted above, however, King concludes his essay by issuing a challenge to absolute notions of falling and stillness. King suggests that one can find pride, and perhaps a kind of power, in the act of falling. He also suggests that willful mobility can exist within stillness. This is where techniques of nonviolent protest intersect with postmodern dance techniques, even though they each emerged out of distinct traditions with specific social and political demands. Although the overwhelming majority of dancers involved in the early years of contact improvisation were white, and likely more socially "free to fall" than people of color in 1970s America, they too were ambivalent about their relationship with gravity and were interested in exploring what King called "the co-presence of mobility and immobility," along with the many falls that exist within any vertical stance $(42)$.

\section{Learning to Fall}

In The Book of Exultation, written in I 925 , dance critic A.K. Volinsky discusses verticality as a fundamental principle of classical ballet. To explain why ballerinas dance on their 
toes, and to make a case for why "everything in ballet is straight, upright, as a taut string that sounds a high note," Volinsky argues that people's impressions vary, depending on whether they see something horizontal or vertical. He states, "In the first case [the horizontal], the psychic sensation is restful and regular, without strong emotion; in the other [the vertical], his soul is made to feel exalted" (Volinsky I 983, 255). Volinsky refers to churches, obelisks, columns, and mountains all as drawing the soul upwards. He even uses the evolutionary claim that man moved from living horizontally to standing vertically, a process Volinsky calls the "greatest bloodless revolution in the history of mankind" $(256)$. He concludes by claiming, "Only in ballet do we possess all aspects of the vertical in its exact mathematically formed, universally perceptible expression" (257).

A. K. Volinsky is not alone in his fascination with ballet's virtuosic engagement with gravity. Although ballet's lightness actually is achieved by rotational downward motion, classical ballet has prized verticality, as did most people writing about Western concert dance before the I 970 os. In "Classic Ballet: Aria of the Aerial," Lincoln Kirstein explains that ballet "accentuates the area of air," using legwork in an attempt to deny gravity (239). The end goal, of course, is flight. Ballet's upward striving reaches its pinnacle in the air, exemplified repeatedly in dance history books by Nijinsky's leap.

In contrast, modern dancers such as Isadora Duncan and Doris Humphrey were curious about the ground as much as the air. Doris Humphrey even founded her technique upon the principles of falling and recovering. According to her writings, as well as commentary by John Martin, Humphrey set out to discover the body's structural proclivities, apart from emotional reactions. She found that falling constitutes one of the body's primary movements. Humphrey explains, "If you stand perfectly still and do not try to control the movement, you will find that you will begin to fall in one direction. You will fall forward or, probably backward, because you have less to hold you up. This seemed to be a very simple discovery, and yet a tremendously important one, if you're going to start a new technique based on body movement"(Stodelle I 978, 20). Friedrich Nietzsche profoundly influenced Humphrey, especially his discussion of the conflict between Apollonian and Dionysian impulses in man. The tension between a desire for stability and the ecstasy of licentiousness and abandon captivated Humphrey (Stodelle 1978, 14). This tension appeared in Humphrey's dance of fall and recovery, with the Apollonian dance of balance and equilibrium matched with the Dionysian fall. In Humphrey's "My Approach to the Modern Dance," she explains:

Falling and recovering is the very stuff of movement, the constant flux which is going on in every living body, in all its tiniest parts, all the time. Nor is this all, for the process has a psychological meaning as well. I recognized these emotional overtones very early and instinctively responded very strongly to the exciting danger of the fall, and the repose and peace of recovery. (Stodelle 1978, I 5)

The oscillation between falling and recovering is evident throughout Humphrey's choreography, most strikingly in dances such as Two Ecstatic Themes ( 93 I), in which Humphrey performs a dance of two parts - the first a slow, circular descent to the ground; the second, an angular assent to standing, ending with arms stretched upward to the sky, 
reminiscent of Volinsky's upward striving. While Humphrey was curious about danger in the act of falling, discourse surrounding her technique generally discusses the fall as yielding or submission, while describing recovery as an act of mastery. When observing Humphrey's choreography, or when learning the technique, one does in fact experience exhilaration in the fall. However, the yielding is always partial. The arms swing, or the torso falls, but there is always the stability of the legs to counterbalance the fall. Or when the legs swing, the torso pulls in opposition. One's entire body never enters a state of free fall, which is where real danger emerges.

As Susan Manning points out in Modern Dance, Negro Dance: Race in Motion, numerous black choreographers-Helmsley Winfield, Edna Guy, and Asadata Dafora in the I 930s, and Katherine Dunham and Pearl Primus in the I940s and I 950s-were active at the same time as Doris Humphrey and the other canonized "founders" of modern dance. When one examines this body of work, especially dances by Dafora (born in Sierra Leone and known for his skillful combinations of African and European performance traditions) and Dunham (an African American choreographer and anthropologist who conducted fieldwork in Cuba, Jamaica, Martinique, Trinidad, and Haiti), it becomes clear that modern dance's rejection of ballet's relation to gravity drew from many sources. Brenda Dixon Gottschild makes this argument in Digging the Africanist Presence in American Performance (I 996). As for modern dancers' relation to gravity and falling, Gottschild argues that "the barefoot dancers reifying contact with the earth, touching it, rolling or lying on it, giving in to it" have African origins (qtd. in Manning 2004, xxiii). She explains, "These particular components of the New Dance had no coordinates in European concert or folk dance traditions. Those traits live in African and African American dance forms, and modern and postmodern dance received this wisdom from Africanist-inspired American vernacular and pop culture" (qtd. in Manning 2004, xxiii).

In actuality, modern dance's emphasis on the ground incorporates a variety of forms, not all of them directly from Africa. For example, classic modern dances such as José Limón's Danzas Mexicanas (1939) and La Malinche (1949), in which dancers stomp the ground rhythmically, derive from Limón's childhood in Mexico and his impressions of Spanish bullfights. Movement forms travel in circuitous routes, often changing as they go. Still, one can detect an Africanist presence in the weightedness of modern dance. Less polemical than Gottschild and more ambivalent about the degree to which Western choreographers intentionally appropriated Africanist elements in their work, Susan Manning and John Perpener illustrate the many interactions between mid-century black and white choreographers: Edna Guy studied with Ruth St. Denis; Charles Williams studied with Doris Humphrey and Hanya Holm; and Pearl Primus studied at the New Dance Group.

Still, none of the modernist choreography that emerged from these interactions embraced falling or stillness in the radical sense noted by Jason King. For black choreographers working in the realm of mid-century concert dance, metaphors of uplift were still at play as they tried to get their work presented and recognized by the press. Metaphors of uplift became especially prominent in the work of Alvin Ailey, an African American choreographer who emerged and achieved wide popularity in the late r950s and early 
r 960 s. Even at the dawn of "postmodern dance," Ailey employed many tenets of the modern tradition, with falls famously followed by recovery. Ailey joined the Lester Horton Dance Theatre in Los Angeles in 1949 and became the company's choreographer after Horton's unexpected death in I 953. The following year, Ailey left for New York, and he formed the Alvin Ailey Dance Company in I 958. From the company's inception, Ailey was committed to making social statements that revealed "the beauty and elegance of black people; their love of self" (Divining Revelations 1986).

In I960 Ailey's company performed Revelations for the first time, a signature piece set to a suite of black spirituals that bore a deep personal connection to Ailey's memories of Baptist churches from his childhood in Texas. When thinking about falling in Ailey's work, one piece stands out: Revelations' solo, "I Want to Be Ready," originally performed by James Truitte but later danced frequently by Dudley Williams. Although Revelations' falls are always followed by recovery, "I Want to Be Ready" suggests the need to be prepared, not just for salvation but also for a range of social and historical constraints. With this austere solo, seemingly with everything at stake, dance emerges as a practice of making oneself ready. Long-limbed and dressed entirely in white, the soloist begins seated in fourth position, hands planted firmly on the floor, gazing upward. A series of stretches and contractions ensues, danced in keeping with the slow cadences of the spiritual, beseeching in deep tones, "I want to be ready / I want to be ready / Lord, ready to put on my long white robe." Several times, the man in white rises from the floor with arms outstretched, only to find the floor again in a controlled, expressive fall. The dance's final descent ends as the man dramatically reaches his right arm across the floor, head down. "I Want to Be Ready" is the last dance in Revelations' middle baptismal section, entitled "Take Me to the Water." The third and final section, "Move, Members, Move," builds to a strong, proud pitch of celebratory dancing by the entire Ailey ensemble. Like the other canonical modernists, Ailey's falls were followed by triumphant recovery-in the case of Revelations, clad in bright-yellow, Sunday best.

While rebellious in many ways, the fall in modern dance was controlled and seldom lasted for long. Even as dancers involved in the Judson Dance Theater began to challenge the modern dancer's vertical stance and relation to gravity during the i $960 \mathrm{os}$, complete inversions and a willingness to suspend control remained anomalous. As Steve Paxton states when discussing Trisha Brown's Trillium, first performed at Maidman Playhouse on March 24, I962, "It was odd to see a handstand in a dance at that time. It was odd to see people off their feet doing anything but a very controlled fall" (qtd. in Banes I 983 , I 2 I). In the realm of concert dance, it would take the postmodern dance experiments of the I 970 , most notably contact improvisation, to rigorously investigate falling and dismantle the corresponding opposition between mastery and submission.

\section{Steve Paxton's “Small Dance"}

In January 1972 Steve Paxton and a group of eleven male students performed Magnesium in an Oberlin College gymnasium. According to Cynthia Novack, people commonly refer to Magnesium as the beginning of contact improvisation, the "seminal work" (Novack 
I 990, 6I). As the men hurl themselves at each other, fall, roll about, and get up again, thunder-like sounds echo throughout the gymnasium. Their arms flail as they collide deliberately and aggressively with one another. After several minutes of this structured, vigorous improvisation, the men rise individually to "The Stand," a signature Paxton exercise also referred to as the "Small Dance." Facing various directions, the men stay motionless for several minutes. While the dancers' vertical stillness contrasts the previous swirl of motion, one nevertheless can detect a slight swaying motion as the dancers move through and around their vertical axes. Paxton explains, "all you have to do is stand up and relax-you know-and at a certain point you realize that you've relaxed everything that you can relax but you're still standing and in that standing is quite a lot of minute movement" (Paxton I997b, 23). In order to stand, there is a constant background noise, a small dance in the body's effort to remain vertical.

In keeping with Jason King's observations about the co-presence of mobility and immobility, Paxton's Stand troubles notions of absolute verticality or bodily stillness. Moreover, as contact improvisation developed as a form, standing was used as a discipline, teaching the dancer that the body works reflexively in a dependable way to protect itself when falling. The goal eventually became to maintain the calmness of the stand even in extreme, adrenalized states of dancing. At one point in Fall After Newton, a video tracing the first eleven years of contact improvisation's development, Paxton discusses Nancy Stark Smith's decisions during a risky fall as the image appears in slow motion. "In order to develop this aspect of the form we had to be able to survive it" (Paxton I $997 \mathrm{a}, \mathrm{I} 43$ ). At this point in the video, Smith cascades from Curt Siddall's shoulder, creating an extended arc downward, only to have her head clear the floor by inches. The video lingers in the moment where her head brushes inches from the floor, presenting smudged traces of her body's arc as she falls slowly toward the ground. Paxton explains, "It is useful to re-train the reflexes to extend the limbs rather than contract them during a fall. During this very disorienting fall, Nancy's arms manage to cradle her back, and this spreads the impact onto a greater area. And she doesn't stop moving" (1997a, I 43).

In the above narration, Paxton emphasizes the need for dancers to re-train their reflexes in order to fall safely. But beyond safety-something of obvious concern to activists training in nonviolent direct action-contact improvisers cultivated an awareness of the many physical possibilities that exist even while falling. As Paxton explains elsewhere in the video's narration, "Beyond [Isaac] Newton's third law, we discover that for every action several equal and opposite reactions are possible. Therein lies an opportunity for improvisation" (1 997a, I42). According to Paxton, dancers have several possibilities in moving through the fall, depending upon momentum, weight distribution between partners, and the overall tone of the improvisation. Although there is no way to tell through video whether dancers react instinctually or by way of conscious design, one nevertheless can trace directional shifts in momentum and discern possible lines of flight or fall in any given moment. This quest for improvisational possibility constitutes a vital skill. Even when dancers appeared "still"-less muscularly held than their modernist forbears-they were in fact engaged in a "small dance," alert and ready to improvise in a variety of ways. 


\section{The Grit of Contact Improvisation}

As dancers became adept at the form and more comfortable with falling, both the "risks" and the look of contact improvisation changed. Nancy Stark Smith explains, "Maybe, because you had seen something on tape, or live, you would try it. If it worked consistently, it might become vocabulary" (qtd. in Novack I 990, 79). Years of analyzing their experiences and imitating successful moves enabled contact improvisers to codify an aesthetic and figure out the mechanics of a new form. As a result, contact improvisation has changed significantly since the early years of Magnesium. The rough and often clunky collisions have turned into fantastic falls as the dancers have learned to listen to their partners and share weight as opposed to merely banging up against it. Smoothness and cooperation between partners became goals. It is not clear, however, that this smoothness signifies untrammeled progress. In a 1984 issue of Contact Quarterly, Nancy Stark Smith recognizes and laments the loss of discord seen in the early days:

I've learned a lot from Contact Improvisation about coordinating with the forces-that-be: Accepting gravity, falling, following momentum, blending with a partner's movements-i.e., "going with the flow." But lately, I've been feeling feisty ... I find myself playing against the forces-making myself heavy instead of light when a lift starts, adding a splash to the easy pouring of weight, insisting instead of yielding, adding fierce to gentle, no to yes. It's a start. I've been in the harmony business a long time now. (Smith I984, 9I)

Over the years, a "grace" has undoubtedly developed in contact improvisation, and Smith seems to have recognized its troubling consequences. It is important, then, to look for moments in contact improvisation where flow gets broken-jarring moments reminiscent of the early Magnesium days but also moments of apparent stillness, or subtle hiccups of miscommunication. As Kent De Spain describes his experience in improvised decision making, "Sometimes in the hyperawareness of improvisation, there are microseconds of stillness between movements (a feeling I might call "hovering") where I sense an actual muscular tension that feels like my body wants to go in several directions" (De Spain r 995, 59). These breaks in flow constitute the often ignored, but crucial, grit of contact improvisation. They serve as visible reminders, for those not actually dancing, that negotiations are taking place, even when the fall appears smooth and full of grace, or when the bodies seem dangerously passive.

Interestingly, Smith's remarks about her newfound feistiness were inspired by a discussion between Steve Paxton and Bill T.Jones, moderated by Mary Overlie on December 4, I 983. This heated debate constitutes a significant "break in flow"; it interrupts narratives about contact improvisation and postmodern dance to insist upon the importance of difference, as well as social and historical context, when considering the political potential of any physical practice. According to Smith, "Several times during the talk [between Jones and Paxton], I felt myself wincing at the action as one might while watching a boxing match when the swing connects" (9I). The discussion, which took place after both dancers performed solos, quickly became edgy as Jones said, "I think that there is a thing which is 
that there are people who are Contact people. Is this true?" (Overlie I 984, 33). Of course, the presumption was that Paxton was and Jones was not a "contact person."

Throughout the conversation, Jones appeared alienated, angry, and at times insecure. He admits that, on the way to the talk, his partner Arnie Zane had urged him not to "let this get polarized, because you and Steve probably have a lot more in common than you do not in common" (34). But the conversation was polarized. Although the two choreographers occasionally found common ground, the tension between them increased throughout the talk. Jones was concerned that Paxton, and the audience, did not like his dancing-that they did not "believe" in what he was doing on stage. In retaliation, Jones claimed that Paxton's inquiry into vibrations and small units of movement was ungenerous. Jones explains, "The only problem I ever had is that I thought that it might be ungenerous.... Your experimentation ... in a way ... I'd like to see more movement. Not necessarily just more, but more about dancing, more about the history" (34).

Each artist made several compelling points. They are both phenomenal dancers, dedicated to thinking about dance. But the two talked past each other, hashing out their respective relationships to dance history and to a particular "tradition." At the time of their conversation, Jones wanted to do big movements in big houses, while Paxton wanted to create a research branch of dance. Arguing that several choreographers already perform large-scale works aimed at entertainment, Paxton asked, "Is it ungenerous to decide that maybe there's a glut of that material on the market?" (35).

Paxton made a valid point, but Jones did not seem to hear it. Arguing that it was no longer I 963 , Jones lambasted "avant-garde" artists who reject tradition, claiming "I feel like, for me, a lot of people making this type of work, they're babies. They really are babies. And they will never grow because they have prejudices, so many prejudices" (36). As a gay, black choreographer, committed in the I 980 s to identity-based work, Jones described both the Judson Dance Theater and the Grand Union as "a bunch of precocious children that were being encouraged to play" (33). When Paxton, who was involved in both projects, objected that the Grand Union and Judson Dance Theater were different endeavors that occurred in different decades, Jones responded, “Oh boy, here we go. Well, to me they're all alike" $\left(3^{6}\right)$.

The tension between Paxton and Jones is palpable even in the written transcript of their conversation. Still, it is important to recognize that Jones did not always feel alienated from contact improvisation. In fact, principles from the technique have had a lasting influence on his career, even as he distanced himself from the social movement. In his memoir, Last Night on Earth, Jones discusses his first encounter with contact improvisation in the mid-I 970s. It was a heady time for Jones, when life as a dancer seemed charged and full of possibility. Having recently transferred from SUNY Binghamton to SUNY Brockport, Jones picked up a flyer on campus: "If you like to rock and roll or lindy hop, do aikido, or make love-come on down and join us at the contact improvisation workshop with Lois Welk" (Jones and Gillespie I 995, I I6). Jones was acquainted with Welk, and he already had begun to appreciate improvisation through classes with Richard Bull. Jones explains, "It was in an improvisation class taught by Richard Bull that I discovered that dance wasn't only about pointing my feet or making lines in space. It was about 
how I could solve problems" ( I I 4). So Jones convinced Arnie Zane to attend the contact workshop with him. They were enlivened by the experience. As a sign of the times, Zane described his initial foray into contact improvisation as "better than tripping" ( I 7 ).

In Welk's workshops, dancers learned the basic principles of contact improvisation: how to dance in physical contact with others, how to "share weight," and how to fall. According to Jones, "Suddenly, dancing was not only about trying to fly. Dancing was about listening, making sense out of an intensely personal exchange as private as lovemaking" ( I I 7). Jones explains that he was ready for the world of contact improvisation, ready for an increased awareness of touch and everyday movement. Reminiscing about his initial exposure to contact improvisation, he explains, "Here I found the delicacy of two foreheads together, the contact point sliding across the eye sockets and down to the chin. Two throats then touching at a single point, then clavicles and shoulders, sternums and bellies.... Physical awareness was richer than ever before" (I I 7 ).

So what happened between Jones's thrilling plunge into the world of contact improvisation and his heated confrontation with Paxton a decade later? As Jones made work with Arnie Zane during the late 1970 s and early 1980 s, a productive tension arose between Zane's reluctance to include autobiographical material in their works and Jones's opposite tendency. Despite a great deal of criticism, Jones increasingly provided a place for the personal in his work. In retrospect, he explains that "we had to respond to the fact that I was a black man who used the word 'nigger' in the context of a work that had been a moment ago — we thought - purely about form, time, repetition, maybe the personalities of the dancers" (Daly I 998, i I 9 ).

At a superficial level, the distinction between "contact people" and "noncontact people" refers to the different trajectories of Jones and Paxton's careers. In a more complicated sense, however, the notion that some people are "contact people" while others are not demands that one consider bodies and their historical circumstances. Jones clearly suggests that contact improvisation was more exclusionary than its practitioners liked to admit. Even within the safety of dance studios, surrounded by contact improvisation's egalitarian rhetoric, imbalances of power abound. It is easier for some to move in particular ways than others, depending on the context, and the stakes are not always the same. Smith's desire to say "no" more often, using her body to obstruct rather than facilitate flow, suggests a desire to complicate gendered compliance. Somewhat similarly, as seen in Ellison and King, historical racism and powerful narratives of uplift complicate the implications of falling and stillness.

In Sbaring the Dance: Contact Improvisation and American Culture, Cynthia Novack notes that contact improvisers, especially in the I970s, viewed the form as an egalitarian communal activity. Recently, Ann Cooper Albright joined Cynthia Novack in lauding contact improvisation's political possibilities. In "Open Bodies: $(\mathrm{X})$ Changes of Identity in Capoeira and Contact Improvisation," Albright argues that contact improvisation offers an improved way of "being-with-others in the world," where dancers learn that "changes and exchanges of identity [are] possible without sacrificing one's own experience of groundedness" (4). According to Albright, these " $(\mathrm{X})$ Changes" arise out of the form's emphasis 
on spontaneity and play, its privileging of disorientation and fluidity, and its willingness to confront "others" in a complex, bodily way, where boundaries begin to blur $(200 \mathrm{I}, 4)$. Albright maintains that one can re-train and re-theorize bodies.

A profound hope for a better world drives Albright's project. Still, her work raises many questions. Surely, dancers can mediate various learned techniques. But can a dancer "re-train" his or her position amidst racism and sexism? Moreover, I wonder about the extent to which a meaningful "exchange of identity" can occur within contact improvisation, especially if it represses or does not acknowledge the sexual, gendered, raced body. I also worry about romanticizing disorientation in a social landscape that is always-already unsteady in its shifting power relations. There are times when disorientation can be a burden, if not outright debilitating.

As seen in the exchange between Paxton and Jones, contact improvisation did not offer a way to transcend difference or fraught social encounters. Power relations did not evaporate as people began to share a dance. Nevertheless, as I have argued throughout this article, contact improvisation, especially as a practice during its early years, did widen the possibilities for improvising within tense situations-provided one could hold onto the importance of "grit" and remember that sometimes one must use one's body as an obstruction rather than go with the flow. A graceful dance does not necessarily indicate progress or harmony, and the blurring of boundaries, even if possible, is not necessarily a good thing.

In closing, I do not wish to suggest that contact improvisation is protest in the sense that the freedom rides were. Nor do I mean to suggest that in situations of violent confrontation, one should start dancing like Nancy Stark Smith. Still, contact improvisation's quest for improvisational possibility even in the midst of falling could be mobilized in other contexts. At its core, contact improvisation is a practice of making oneself ready for a range of ever-shifting surprises and constraints. When one looks to historical situations in which people have strategically "put their bodies on the line," one begins to see the power of a bodily training such as contact improvisation that seeks choices and opportunities for agency-the calmness that gets practiced in the stand-even in situations of duress.

\section{Note}

I. Here I am referring to Cynthia Novack's famous book, Sharing the Dance: Contact Improvisation and American Culture.

\section{Works Cited}

Albright, Ann Cooper. 200r. "Open Bodies: (X)Changes of Identity in Capoeira and Contact Improvisation." In CORD 200 I: Transmigratory Moves: Dance in Global Circulation. New York: New York University Press.

Banes, Sally. 1983. Democracy's Body: Judson Dance Theater, 1962-1964. Ann Arbor: UMI Research Press. 
Branch, Taylor. 1 989. Parting the Waters: America in the King Years, 1954-1963. New York: Simon and Schuster.

Browning, Barbara. 2004. "Choreographing Postcoloniality: Reflections on the Passing of Edward Said." Dance Research Journal 35 (2) and 36 (2): I64-69.

Cozzens, Lisa. 1 997 . Freedom Rides. Accessed May 2, 2006, from http://www.watson.org/ lisa/ blackhistory/civilrights-55-65/freeride.html.

Daly, Ann. I 998. "Bill T. Jones in Conversation with Ann Daly." In Art Performs Life: Merce Cunningham/Meredith Monk/Bill T. Jones. Minneapolis: Walker Arts Center.

De Spain, Kent. I 995. "A Moving Decision: Notes on the Improvising Mind." Contact Quarterly 20 (I): 48-50.

Divining Revelations: An Evening with Alvin Ailey Dance Theater. 1986. DVD. RM Arts/Danmakrs Radio Musikafdelingen.

Ellison, Ralph. 1947. Invisible Man. New York: Vintage International.

Foster, Susan Leigh. 2003. "Choreographies of Protest." Theatre Journal 55 (3): 395-4I 2.

Gottschild, Brenda Dixon. 1996. Digging the Africanist Presence in American Performance: Dance and Other Contexts. Westport, CT: Greenwood Press.

Jones, Bill T., and Peggy Gillespie. I 995. Last Night on Earth. New York: Pantheon.

King, Jason. 2004. "Which Way Is Down? Improvisations On Black Mobility." Women And Performance: A Journal of Feminist Theory 1 4: I (27): 24-25.

Kirstein, Lincoln. 1983 . “Classic Ballet: Aria of the Aerial." In What Is Dance: Readings in Theory and Criticism, 238-43. Edited by Roger Copeland and Marshall Cohen. Oxford: Oxford University Press.

Manning, Susan. 2004. Modern Dance, Negro Dance: Race in Motion. Minneapolis: University of Minnesota Press.

Meier, August, and Elliott Rudwick. 1973. Core: A Study in the Civil Rights Movement, 1942-1968. Oxford: Oxford University Press.

Novack, Cynthia. 1990. Sharing the Dance: Contact Improvisation and American Culture. Madison: University of Wisconsin Press.

Oppenheimer, Martin, and George Lakey. 1 964. A Manual For Direct Action. Foreword by Bayard Rustin. Chicago: Quadrangle.

Overlie, Mary. I 984 . "The Studies Project." Contact Quarterly 9 (3): 30-37.

Paxton, Steve. I 997a. "Fall After Newton." Contact Quarterly's Contact Improvisation Sourcebook: Collected Writings and Graphics from Contact Quarterly Dance Journal 1975-1992, 142-43. Ed. Lisa Nelson and Nancy Stark Smith. Northampton: Contact Editions.

. I 997b. “The Small Dance: Elizabeth Zimmer interviewing Steve Paxton." Contact Quarterly's Contact Improvisation Sourcebook: Collected Writings and Graphics from Contact Quarterly Dance Journal 1975-1992, 23. Edited by Lisa Nelson and Nancy Stark Smith. Northampton: Contact Editions.

Smith, Nancy Stark. I984. "Dealing with the Heat." Contact Quarterly 9 (3): 3.

Stodelle, Ernestine. 1 978. The Dance Technique of Doris Humphrey and Its Creative Potential. and ed. Princeton, NJ: Princeton Book.

Volinsky, A. K. I 983. "The Vertical: The Fundamental Principle of Classic Dance." What Is Dance: Readings in Theory and Criticism, 255-56. Edited by Roger Copeland and Marshall Cohen. Oxford: Oxford University Press. 